\title{
INFLUENCE OF THE USE OF SCAFFOLD ON THE REGENERATION POTENTIAL OF NECROTIC IMMATURE HUMAN PERMANENT ANTERIOR TEETH: CLINICAL STUDY
}

\author{
Ahmed M. Khalil ${ }^{*}$, Kareem El- Batoty ${ }^{* *}$ and Mohamed M. Nagi***
}

\begin{abstract}
Aim of the Study: The aim of this study was to assess the influence of using EMD as a scaffold in pulp revascularization as compared to the conventional MTA revascularization.

Patients and Methods: 30 patients with immature necrotic permanent anterior were selected and enrolled in this study. Patients were divided into two groups, group A was treated using EMD and MTA plug scaffold while group B was treated using conventional MTA plug and blood clot. Clinical evaluation as well as radiographic assessment of apical constriction diameter for both groups were done at 3-, 6-, 9- and 12-months intervals.
\end{abstract}

Results: There was no statistically significant difference between the two groups at the end of the whole follow up period.

Conclusion: The use of EMD with MTA in pulp regeneration has no better effect in increasing the apical diameter than the use of MTA alone.

KEYWORDS: Pulp revascularization, Pulp regeneration, Enamel matrix derivative, Emdogain

\section{INTRODUCTION}

Revascularization was first presented by Ostby, 1961. The revascularization procedure relies upon the acceptance of seeping through the open apical foramen intra the chemically cleaned canal. The canal dentin and the blood clot give scaffolds in the root channel revascularization (Banchs and Trope, 2004).
EMD is produced using an enamel matrix derivative from Hertwig's epithelial sheath during porcine tooth development (Hammarström, 1997; Bosshardt and Nanci, 2004). This enamel matrix derivative contains amelogenin as its main part notwithstanding other enamel matrix proteins, for example, enamelins, tuftelin, amelin, and ameloblastin (Krebsbach et al., 1996). It considered important regulator of mineralization

\footnotetext{
* Master Degree Student, Endodontics Department, Ain Shams University, Cairo, Egypt.

** Professor, Endodontics Department, Ain Shams University, Cairo, Egypt.

*** Assistant Professor, Endodontics Department, Ain Shams University, Cairo, Egypt.
} 
of enamel (Robinson et al., 1998) and assumes a significant part during periodontal tissue development (Hammarström, 1997; Bosshardt and Nanci, 2004).

Matsumoto et al., 2014 discovered convincingly that EMD doesn't aggravate damaged periapical tissue and may establish a great climate that advances the healing of injured periapical tissues.

Therefore, the purpose of this study was to investigate the use of scaffolded revascularization using EMD with MTA in comparison to conventional MTA revascularization in human permanent anterior teeth.

\section{PATIENTS AND METHODS}

\section{Selection of patients:}

Based on previous studies Nagy et al., 2014, a total sample size of 24 patients was calculated*. 30 patients with immature, non-vital single rooted teeth presenting with or without signs and/or symptoms of periapical pathology were included in the study from the clinic of Faculty of Dentistry, Ain shams University, Cairo, Egypt. A detailed dental and medical history were obtained from every patient or guardians, only systemically healthy patients were included in the study.

\section{Inclusion criteria}

1. Age 8-15.

2. Medically free patients.

3. Single rooted immature necrotic permanent teeth.

4. Teeth without vertical root fracture or resorption.

\section{Exclusion criteria}

1. Avulsed teeth immediately after replantation (as revitalization may occur naturally).

* IBM $^{\mathrm{TM}}$ SPSS $^{\mathrm{TM}}$ SamplePower ${ }^{\mathrm{TM}}$
2. Luxation injuries.

3. I nadequate tooth isolation.

4. Teeth with severe loss of coronal tissue that require restoration with a post that will occupy the space required for blood clot formation.

5. Medically compromised patients.

\section{Classification of patients:}

Cases were divided into two groups, fifteen patients each group $(n=15)$.

Group A ( $\mathrm{n}=15)$ treatment had been approached using scaffold regeneration.

Group B $(n=15)$ treatment had been approached using conventional regeneration.

\section{Clinical procedures (according to AAE clinical considerations):}

\section{First Visit:}

a) Preoperative digital radiograph ${ }^{* *}$ was obtained using standardized paralleling technique with Rinn XCP alignment system ${ }^{* * *}$.

b) Patients were given local anesthesia****

c) Dental dam isolation then access was done.

d) Copious, gentle irrigation was done using $1.5 \%$ sodium hypochlorite $(20 \mathrm{~mL})$ using needle with closed end and side-vents to minimize the possibility of extrusion of irrigants into the periapical space and then irrigated with $17 \%$ EDTA $^{* * * * *}$ $(20 \mathrm{~mL})$, with irrigating needle positioned about $1 \mathrm{~mm}$ from root end.

e) Calcium hydroxide was injected to the full length of the canals after drying the canals with sterile paper points.

\footnotetext{
** Fona, Italy

*** Rinn Corporation, Elgin, IL, USA

**** Mepecaine 3\% cartilage $1.8 \mathrm{ml}$, Alexandria co., Egypt

***** Meta Biomed, Korea
} 
f) A sterile cotton pellet was inserted to the pulp chamber and the access cavity was sealed with a temporary restoration*.

\section{Second Visit: (After 1-3 weeks from the first visit)}

- The second visit was scheduled for the patient when there are no signs of periapical discharge, and the tooth is asymptomatic.

- If there was any signs of discharge or persistent symptoms, one or more visits was scheduled to eradicate the symptoms.

- Cases were divided to two groups according to the revascularization protocol, eighteen patients each group $(n=18)$.

- Patients were allocated randomly in their respective groups using sealed envelopes for randomization.

\section{Group A}

1. The patients were given plain anesthesia**, proper isolation was done; the temporary restoration and cotton pellet were removed.

2. Canals were irrigated with $20 \mathrm{ml}$ of $17 \%$ EDTA for 1 minute.

3. Canals were then dried using sterile paper points.

4. A sterile hand file size \#50 was used in sharp strokes $2 \mathrm{~mm}$ beyond the apex into the peri-apical tissues until bleeding was evident in cervical portion of the canal.

5. $\mathrm{EMD}^{* * * *}$ was injected inside the canal on the blood clot up to the CEJ to act as a matrix for the cells.

6. White MTA was placed at the orifice, over the EMD and the blood clot to seal the canal orifice with a wet sterile cotton pellet above.

\footnotetext{
* Coltosol F; Coltene Whaledent, Altstatten,

** Switzerland

** scandonest $3 \%$ plain, septodont, Saint- Maur-DesFosses-France

*** Straumann ${ }^{\circledR}$ Emdogain ${ }^{\circledR}$, Germany
}

7. Temporary filling was used to seal the cavity.

8. After 1-2 days composite resin was used to seal the access cavity.

\section{GROUP B}

1. The patients were given plain anesthesia, proper isolation was done; the temporary restoration and cotton pellet were removed.

2. Canals were irrigated with $20 \mathrm{ml}$ of $17 \%$ EDTA for 1 minute.

3. Canals were then dried using sterile paper points.

4. A sterile hand file size \#50 was used in sharp strokes $2 \mathrm{~mm}$ beyond the apex into the peri-apical tissues until bleeding was evident in cervical portion of the canal.

5. White MTA was placed at the orifice, over the blood clot to seal the canal orifice with a wet sterile cotton pellet above.

6. Temporary filling was used to seal the cavity.

After 1-2 days composite resin was used to seal the access cavity.

\section{Methods of Evaluation}

Patients were recalled at 3, 6, 9 and 12 months. Follow up included the clinical assessment of pain and/or swelling and standardized radiographic assessment which included the following Nagy et al., 2014:

\section{Increase in root length:}

A measuring scale was set in the Image-J software by measuring a known clinical dimension to its radiographic dimension. The scale was measured as number of pixels per mm length. Root lengths were measured as a straight line from the Incisal edge to the radiographic apex of the tooth in millimeters. Pre and follow-up root lengths were measured and the difference in root length was calculated as shown in figure (1). Percentage of 
increase in length was calculated as follows:

\section{$\%$ Increase in Length =}

$\frac{\text { Postoperative Length - Preoperative length }}{\text { Preoperative length }} \times 100$

\section{Increase in root thickness:}

Utilizing the preset measurement scale, the level of the apical third was resolved and fixed from the cementoenamel junction. The root thickness and the pulp width were estimated at this level in millimeters. Dentin thickness was estimated by deduction of the pulp space from the entire root thickness. Estimations were done pre- and post-operatively at the same fixed level as demonstrated in figure (2). The distinction in thickness was determined. Percentage

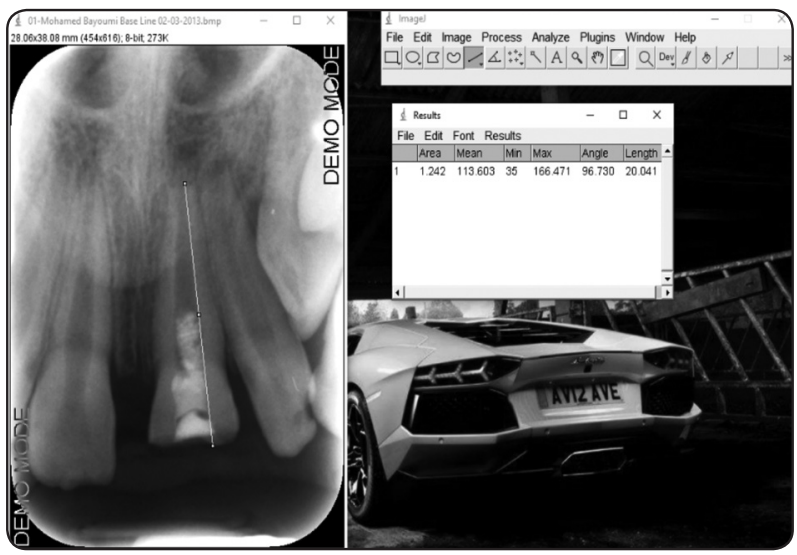

Fig. (1) Photograph Showing Digital Measurement of Root Length Using Image J Software.

of increase in dentin thickness was determined as follows:

Dentin thickness $=$ root thickness - pulp width $\%$ Increase in Thickness =

Postoperative thickness - preoperative thickness P ostoperative thickness

\section{Decrease in apical diameter:}

Using the preset measurement scale, the diameter of the apical foramen was measured in millimeters. Measurements were done pre- and post-operatively as shown in figure (3). The difference in apical

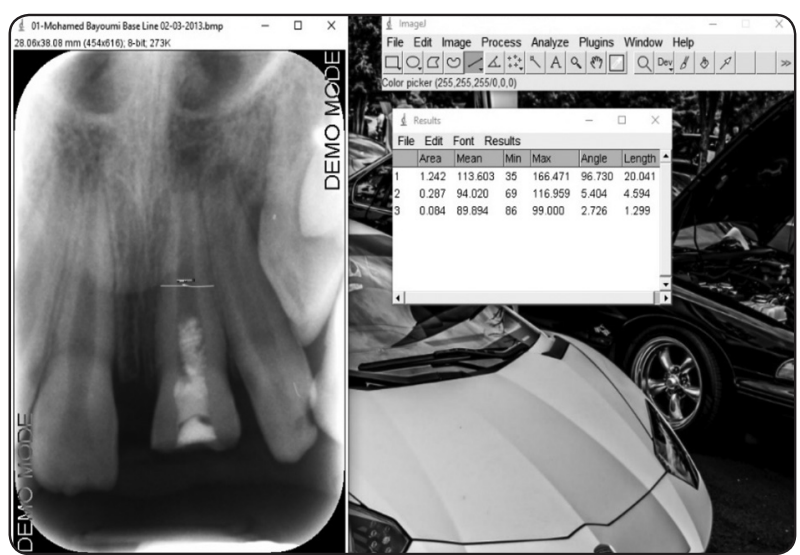

Fig. (2) Photograph Showing Digital Measurement of Root Thickness Using Image J Software.

diameter was calculated. Percentage of apical closure was calculated as follows:

\section{\%Apical Closure =}

Preoperative apical diameter - Postoperative apical diameter x 100 Preoperative apical diameter

\section{RESULTS}

The present study was conducted on 30 patients selected from the outpatient clinic of Endodontic department, Ain shams University.

The study included 30 patients, 19 males (10 group A \& 9 group B) and 11 females (5 group A \& 6 group B). For the 30 included patients ages ranged from 8 - 12 years with a mean of 10 years.

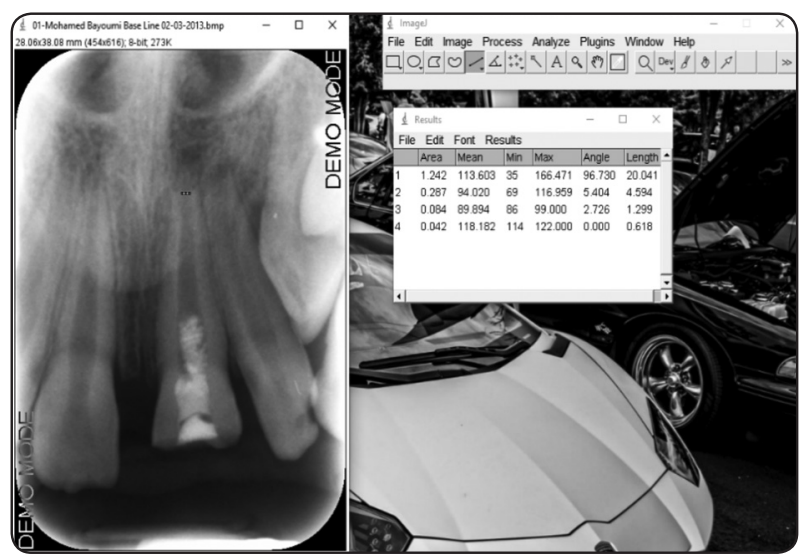

Fig. (3): Photograph Showing Digital Measurement of The Apical Diameter Using Image J Software. 


\section{Tooth length:}

Data were calculated and tabulated in (Table 1, Table 2) (Figure 4, Figure 5).

TABLE (1): The mean, standard deviation (SD) percentage of change in tooth length of different groups

\begin{tabular}{cccccc}
\hline \multirow{3}{*}{ Variables } & \multicolumn{4}{c}{ Tooth length } \\
\cline { 2 - 5 } & $\begin{array}{c}\text { Group A } \\
\text { (Emdogain) }\end{array}$ & \multicolumn{2}{c}{ Group B } & p-value \\
& (Conventional) & \\
\cline { 2 - 5 } & Mean & SD & Mean & SD & \\
\hline \multirow{2}{*}{ Bl-12m } & $4.45^{\text {a }}$ & 0.36 & $5.02^{\text {a }}$ & 0.62 & $\mathbf{0 . 1 1 5 n s}$ \\
\hline
\end{tabular}

Means with same letters in the same row indicates nonsignificant difference.

ns; non-significant

TABLE (2): The mean, standard deviation (SD) percentage of change in tooth length of different groups throw the follow up intervals

\begin{tabular}{|c|c|c|c|c|c|}
\hline \multirow{3}{*}{ Variables } & \multicolumn{5}{|c|}{ Tooth length } \\
\hline & \multicolumn{2}{|c|}{$\begin{array}{c}\text { Group A } \\
\text { (Emdogain) }\end{array}$} & \multicolumn{2}{|c|}{$\begin{array}{c}\text { Group B } \\
\text { (Conventional) }\end{array}$} & \multirow[t]{2}{*}{ p-value } \\
\hline & Mean & SD & Mean & SD & \\
\hline Bl-3m & $2.83^{\mathrm{cA}}$ & 0.06 & $2.42^{\mathrm{dB}}$ & 0.08 & $<0.001 *$ \\
\hline $3 m-6 m$ & $3.1^{\mathrm{bA}}$ & 0.12 & $2.47^{\mathrm{cdB}}$ & 0.07 & $<0.001 *$ \\
\hline $6 m-9 m$ & $2.22^{\mathrm{dB}}$ & 0.02 & $3.56^{\mathrm{bA}}$ & 0.28 & $<0.001 *$ \\
\hline $9 m-12 m$ & $2.29 \mathrm{~dB}$ & 0.06 & $2.54^{\mathrm{cA}}$ & 0.06 & $<0.001 *$ \\
\hline p-value & \multicolumn{2}{|c|}{$<0.001 *$} & \multicolumn{2}{|c|}{$<0.001 *$} & \\
\hline
\end{tabular}

Means with different small letters in the same column indicates significant difference, means with different capital letter in the same row indicates significant difference

*; significant $(p<0.05) \quad n s ;$ non-significant $(p>0.05)$

In group A "Emdogain", the mean percentage of increase in root length was $2.83 \pm 0.06 \%$ after 3 months of follow up, $3.1 \pm 0.12 \%$ after 6 months of follow up, $2.22 \pm 0.02 \%$ after 9 months of follow up and $2.29 \pm 0.06 \%$ after 12 months of follow up. In group A "Emdogain", the total mean percentage of increase in root length was $4.45 \pm 0.36 \%$.

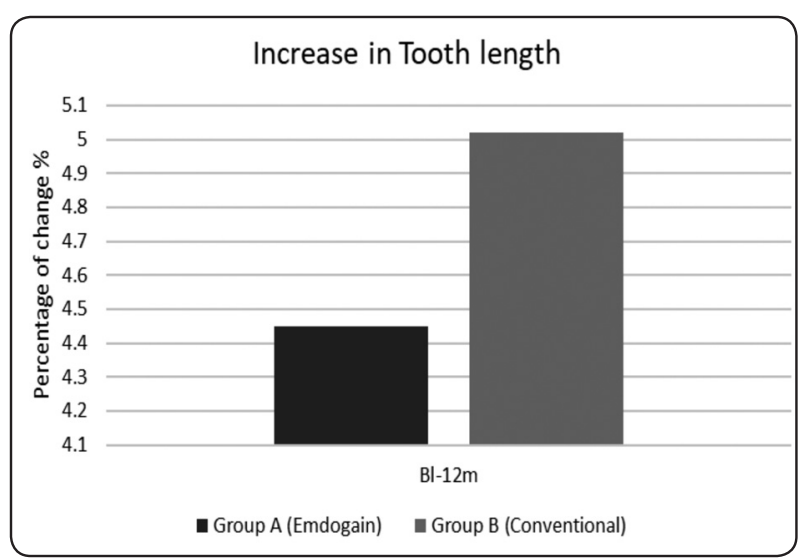

Fig. (4): Bar chart representing tooth length for different groups

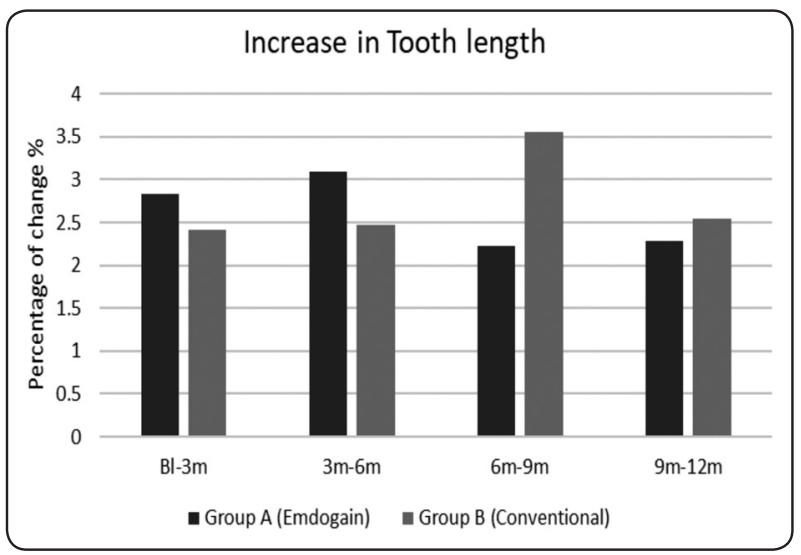

Fig. (5): Bar chart representing tooth length for different groups throw the follow up intervals

In group B "Conventional", the mean percentage of increase in root length was $2.42 \pm 0.08 \%$ after 3 months of follow up, $2.47 \pm 0.07 \%$ after 6 months of follow up, $3.56 \pm 0.28 \%$ after 9 months of follow up and $2.54 \pm 0.06 \%$ after 12 months of follow up. In group B "Conventional", the total mean percentage of increase in root length was $5.02 \pm 0.62 \%$.

\section{Effect of time}

\section{Group A (Emdogain)}

There was a statistically significant difference between (BL-3m) (3m-6m), (6m-9m), (9m-12m) and $(\mathrm{BL}-12 \mathrm{~m})$ groups where $(p<0.001)$.

A statistically significant difference was found between (BL-3m) and each of (3m-6m), (6m-9m), 
$(9 \mathrm{~m}-12 \mathrm{~m})$ and $(\mathrm{BL}-12 \mathrm{~m})$ groups where $(\mathrm{p}=0.003)$, $(\mathrm{p}<0.001),(\mathrm{p}<0.001)$ and $(\mathrm{p}=0.001)$ respectively.

Also, a statistically significant difference was found between $(3 m-6 m)$ and each of $(6 m-9 m)$, $(9 \mathrm{~m}-12 \mathrm{~m})$ and $(\mathrm{BL}-12 \mathrm{~m})$ groups where $(\mathrm{p}<0.001)$, $(\mathrm{p}<0.001)$ and $(\mathrm{p}=0.002)$ respectively.

No statistically significant difference was found between $(6 m-9 m)$ and $(9 m-12 m)$ where $(p=0.063)$, while a statistically significant difference was found between $(6 \mathrm{~m}-9 \mathrm{~m})$ and $(\mathrm{BL}-12 \mathrm{~m})$ groups where $(\mathrm{p}<0.001)$

Also, a statistically significant difference was found between (9m-12m) and (BL-12m) groups where $(\mathrm{p}<0.001)$.

\section{Group B (Conventional):}

There was a statistically significant difference between (BL-3m) (3m-6m), (6m-9m), (9m-12m) and $(B L-12 \mathrm{~m})$ groups where $(\mathrm{p}<0.001)$.

No statistically significant difference was found between $(\mathrm{Bl}-3 \mathrm{~m})$ and $(3 \mathrm{~m}-6 \mathrm{~m})$ where $(\mathrm{p}=0.498)$. A statistically significant difference was found between (BL-3m) and each of (6m-9m), (9m-12m) and $(\mathrm{BL}-12 \mathrm{~m})$ groups where $(\mathrm{p}=0.002),(\mathrm{p}=0.020)$ and $(\mathrm{p}=0.001)$ respectively.

Also, a statistically significant difference was found between $(3 \mathrm{~m}-6 \mathrm{~m})$ and each of $(6 \mathrm{~m}-9 \mathrm{~m})$ and $(B L-12 m)$ groups where $(p<0.001)$ and $(p=0.001)$ respectively. While no statistically significant difference was found between $(3 \mathrm{~m}-6 \mathrm{~m})$ and each of $(9 \mathrm{~m}-12 \mathrm{~m})$ where $(\mathrm{p}=0.208)$.

A statistically significant difference was found between $(6 m-9 m)$ and each of $(9 m-12 m)$ and $(\mathrm{BL}-12 \mathrm{~m})$ groups where $(\mathrm{p}=0.002)$ and $(\mathrm{p}=0.005)$ respectively.

Also, a statistically significant difference was found between $(9 \mathrm{~m}-12 \mathrm{~m})$ and $(\mathrm{BL}-12 \mathrm{~m})$ groups where $(p=0.001)$.

\section{Relation between groups:}

\section{a) Bl-3m:}

There was a statistically significant difference between (Group A) and (Group B) groups where $(\mathrm{p}<0.001)$.

\section{b) $3 m-6 m$ :}

There was a statistically significant difference between (Group A) and (Group B) groups where $(\mathrm{p}<0.001)$.

\section{c) $6 m-9 m:$}

There was a statistically significant difference between (Group A) and (Group B) groups where $(\mathrm{p}<0.001)$.

\section{d) 9m-12m:}

There was a statistically significant difference between (Group A) and (Group B) groups where $(\mathrm{p}<0.001)$.

\section{e) Bl-12m:}

There was no statistically significant difference between (Group A) and (Group B) groups where $(\mathrm{p}=0.115)$.

\section{Dentin thickness:}

Data were calculated and tabulated in (Table 3, Table 4) (Figure 6, Figure 7).

In group A "Emdogain", the mean percentage of increase in dentin thickness was $6.9 \pm 0.91 \%$ after 3 months of follow up, $3.03 \pm 0.78 \%$ after 6 months of follow up, $2.94 \pm 0.4 \%$ after 9 months of follow up and $1.58 \pm 0.12 \%$ after 12 months of follow up. In group A "Emdogain", the total mean percentage of increase in dentin thickness was $15.08 \pm 2.49 \%$.

In group B "Conventional", the mean percentage of increase in dentin thickness was $2.28 \pm 0.15 \%$ after 3 months of follow up, $0.7 \pm 0.06 \%$ after 6 months of follow up, $0.77 \pm 0.07 \%$ after 9 months of follow up and $0.58 \pm 0.05 \%$ after 12 months of follow up. In 
group B "Conventional”, the total mean percentage of increase in dentin thickness was $4.39 \pm 0.72 \%$.

TABLE (3): The mean, standard deviation (SD) values of change in dentin thickness of different groups

\begin{tabular}{lccccc}
\hline \multirow{3}{*}{ Variables } & \multicolumn{5}{c}{ Dentin thickness } \\
\cline { 2 - 5 } & $\begin{array}{c}\text { Group A } \\
\text { (Emdogain) }\end{array}$ & \multicolumn{2}{c}{$\begin{array}{c}\text { Group B } \\
\text { (Conventional) }\end{array}$} & p-value \\
\cline { 2 - 5 } & Mean & SD & Mean & SD & \\
\hline Bl-12m & $15.08^{\text {a }}$ & 2.49 & $4.39^{\mathrm{b}}$ & 0.72 & $<\mathbf{0 . 0 0 1 *}$ \\
\hline
\end{tabular}

Means with different letters in the same row indicates significant difference.

*; significant

TABLE (4): The mean, standard deviation (SD) values of change in dentin thickness of different groups throw the follow up intervals

\begin{tabular}{lccccc}
\hline & \multicolumn{5}{c}{ Dentin thickness } \\
\cline { 2 - 5 } Variables & $\begin{array}{c}\text { Group A } \\
\text { (Emdogain) }\end{array}$ & \multicolumn{2}{c}{ Group B } \\
& (Conventional) & p-value \\
\cline { 2 - 5 } & Mean & SD & Mean & SD & \\
\hline Bl-3m & $6.90^{\mathrm{bA}}$ & 0.91 & $2.28^{\mathrm{bB}}$ & 0.15 & $<\mathbf{0 . 0 0 1 *}$ \\
$\mathbf{3 m - 6 m}$ & $3.03^{\mathrm{cA}}$ & 0.78 & $0.70^{\mathrm{cB}}$ & 0.06 & $<\mathbf{0 . 0 0 1 *}$ \\
$\mathbf{6 m - 9 m}$ & $2.94^{\mathrm{cA}}$ & 0.40 & $0.77^{\mathrm{cB}}$ & 0.07 & $<\mathbf{0 . 0 0 1 *}$ \\
$\mathbf{9 m - 1 2 m}$ & $1.58^{\mathrm{dA}}$ & 0.12 & $0.58^{\mathrm{dB}}$ & 0.05 & $<\mathbf{0 . 0 0 1 *}$ \\
\hline $\mathbf{p}$-value & $<\mathbf{0 . 0 0 1 *}$ & $<\mathbf{0 . 0 0 1 *}$ & \\
\hline
\end{tabular}

Means with different small letters in the same column indicates significant difference, means with different capital letter in the same row indicates significant difference

*; significant $(p<0.05) \quad n s ;$ non-significant $(p>0.05)$

\section{Effect of time:}

\section{Group A (Emdogain):}

There was a statistically significant difference between (BL-3m) (3m-6m), (6m-9m), (9m-12m) and $(B L-12 \mathrm{~m})$ groups where $(\mathrm{p}<0.001)$.

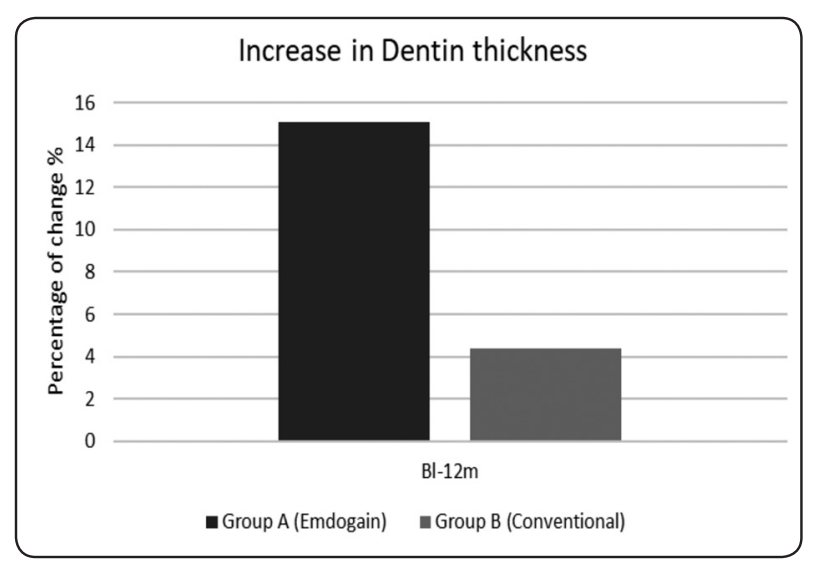

Fig. (6): Bar chart representing dentin thickness for different groups

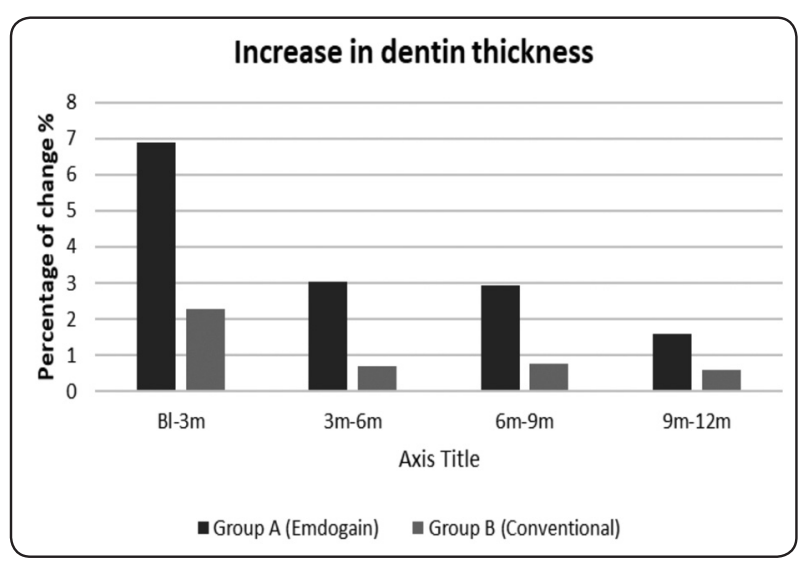

Fig. (7): Bar chart representing dentin thickness for different groups throw the follow up intervals

A statistically significant difference was found between (BL-3m) and each of (3m-6m), (6m-9m), $(9 \mathrm{~m}-12 \mathrm{~m})$ and $(\mathrm{BL}-12 \mathrm{~m})$ groups where $(\mathrm{p}<0.001)$, $(\mathrm{p}=0.002),(\mathrm{p}<0.001)$ and $(\mathrm{p}=0.005)$ respectively.

No statistically significant difference was found between $(3 \mathrm{~m}-6 \mathrm{~m})$ and $(6 \mathrm{~m}-9 \mathrm{~m})$ where $(\mathrm{p}=0.857)$, while a statistically significant difference was found between $(3 m-6 m)$ and each of $(9 m-12 m)$ and $(\mathrm{BL}-12 \mathrm{~m})$ groups where $(\mathrm{p}=0.009)$ and $(\mathrm{p}=0.001)$ respectively.

A statistically significant difference was found between $(6 m-9 m)$ and each of $(9 m-12 m)$ and $(\mathrm{BL}-12 \mathrm{~m})$ groups where $(\mathrm{p}=0.003)$ and $(\mathrm{p}<0.001)$ respectively. 
Also, a statistically significant difference was found between $(9 \mathrm{~m}-12 \mathrm{~m})$ and (BL-12m) groups where $(\mathrm{p}<0.001)$.

\section{Group B (Conventional):}

There was a statistically significant difference between (BL-3m) (3m-6m), (6m-9m), (9m-12m) and $(\mathrm{BL}-12 \mathrm{~m})$ groups where $(\mathrm{p}<0.001)$.

A statistically significant difference was found between (BL-3m) and each of (3m-6m), (6m-9m), $(9 \mathrm{~m}-12 \mathrm{~m})$ and $(\mathrm{BL}-12 \mathrm{~m})$ groups where $(\mathrm{p}<0.001)$, $(p<0.001),(p<0.001)$ and $(p=0.002)$ respectively.

No statistically significant difference was found between $(3 m-6 m)$ and $(6 m-9 m)$ where $(p=0.206)$, while a statistically significant difference was found between (3m-6m) and each of (9m-12m) and $(\mathrm{BL}-12 \mathrm{~m})$ groups where $(\mathrm{p}=0.011)$ and $(\mathrm{p}<0.001)$ respectively.

A statistically significant difference was found between (6m-9m) and each of (9m-12m) and $(\mathrm{BL}-12 \mathrm{~m})$ groups where $(\mathrm{p}=0.027)$ and $(\mathrm{p}<0.001)$ respectively.

Also, a statistically significant difference was found between (9m-12m) and (BL-12m) groups where $(\mathrm{p}<0.001)$.

\section{Relation between groups:}

\section{a) Bl-3m:}

There was a statistically significant difference between (Group A) and (Group B) groups where $(\mathrm{p}<0.001)$.

\section{b) $3 m-6 m$ :}

There was a statistically significant difference between (Group A) and (Group B) groups where $(\mathrm{p}<0.001)$.

\section{c) $6 m-9 m:$}

There was a statistically significant difference between (Group A) and (Group B) groups where $(\mathrm{p}<0.001)$.

\section{d) $9 m-12 m:$}

There was a statistically significant difference between (Group A) and (Group B) groups where $(\mathrm{p}<0.001)$.

\section{e) Bl-12m:}

There was a statistically significant difference between (Group A) and (Group B) groups where $(\mathrm{p}<0.001)$.

\section{Apical diameter:}

Data were calculated and tabulated in (Table 5, Table 6) (Figure 8, Figure 9).

In group A "Emdogain", the mean percentage of increase in apical diameter was $10.13 \pm 0.46 \%$ after 3 months of follow up, $13.95 \pm 1.03 \%$ after 6 months of follow up, $18.76 \pm 1.39 \%$ after 9 months of follow up and $14.60 \pm 3.44 \%$ after 12 months of follow up. In group A "Emdogain", the total mean percentage of increase in apical diameter was $97.53 \pm 1.40 \%$.

In group B "Conventional", the mean percentage of increase in apical diameter was $6.00 \pm 0.91 \%$ after 3 months of follow up, $17.29 \pm 4.96 \%$ after 6 months of follow up, $18.88 \pm 1.63 \%$ after 9 months of follow up and $17.98 \pm 3.19 \%$ after 12 months of follow up. In group B "Conventional", the total mean percentage of increase in apical diameter was $96.69 \pm 2.36 \%$.

\section{Effect of time:}

\section{Group A (Emdogain):}

There was a statistically significant difference between (BL-3m) (3m-6m), (6m-9m), (9m-12m) and $(B L-12 \mathrm{~m})$ groups where $(\mathrm{p}<0.001)$. 
TABLE (5): The mean, standard deviation (SD) values of change in apical diameter of different groups

\begin{tabular}{cccccc}
\hline & \multicolumn{4}{c}{ Apical diameter } \\
\cline { 2 - 5 } Variables & $\begin{array}{c}\text { Group A } \\
\text { (Emdogain) }\end{array}$ & \multicolumn{2}{c}{$\begin{array}{c}\text { Group B } \\
\text { (Conventional) }\end{array}$} & p-value \\
\cline { 2 - 5 } & Mean & SD & Mean & SD & \\
\hline \multirow{2}{*}{ B1-12m } & $97.53^{\text {a }}$ & 1.40 & $96.69^{\text {a }}$ & 2.36 & $\mathbf{0 . 5 1 2 n s}$ \\
\hline
\end{tabular}

Means with same letters in the same row indicates nonsignificant difference

ns; non-significant

TABLE (6): The mean, standard deviation (SD) values of change in apical diameter of different groups throw the follow up intervals

\begin{tabular}{|c|c|c|c|c|c|}
\hline \multirow{3}{*}{ Variables } & \multicolumn{5}{|c|}{ Apical diameter } \\
\hline & \multicolumn{2}{|c|}{$\begin{array}{c}\text { Group A } \\
\text { (Endogain) }\end{array}$} & \multicolumn{2}{|c|}{$\begin{array}{c}\text { Group B } \\
\text { (Conventional) }\end{array}$} & \multirow[t]{2}{*}{ p-value } \\
\hline & Mean & SD & Mean & SD & \\
\hline Bl-3m & $10.13^{\mathrm{dA}}$ & 0.46 & $6.00^{\mathrm{cB}}$ & 0.91 & $<0.001 *$ \\
\hline $3 m-6 m$ & $13.95^{\mathrm{cA}}$ & 1.03 & $17.29^{\mathrm{bA}}$ & 4.96 & $0.179 n s$ \\
\hline $6 m-9 m$ & $18.76^{\mathrm{bA}}$ & 1.39 & $18.88^{\mathrm{bA}}$ & 1.63 & $0.907 n s$ \\
\hline $9 m-12 m$ & $14.60^{\mathrm{cdA}}$ & 3.44 & $17.98^{\mathrm{bA}}$ & 3.19 & $0.147 n s$ \\
\hline Bl-12m & $97.53^{\mathrm{aA}}$ & 1.40 & $96.69^{\mathrm{aA}}$ & 2.36 & $0.512 \mathrm{~ns}$ \\
\hline p-value & \multicolumn{2}{|c|}{$<0.001 *$} & \multicolumn{2}{|c|}{$<0.001 *$} & \\
\hline
\end{tabular}

Means with different small letters in the same column indicates significant difference, means with different capital letter in the same row indicates significant difference

*; significant $(p<0.05) \quad n s ;$ non-significant $(p>0.05)$

A statistically significant difference was found between (BL-3m) and each of (3m-6m), (6m-9m) and $(\mathrm{BL}-12 \mathrm{~m})$ groups where $(\mathrm{p}=0.002),(\mathrm{p}<0.001)$ and $(\mathrm{p}<0.001)$ respectively. While no statistically significant difference was found between (BL-3m) and $(9 \mathrm{~m}-12 \mathrm{~m})$ where $(\mathrm{p}=0.050)$.

Also, a statistically significant difference was found between $(3 \mathrm{~m}-6 \mathrm{~m})$ and each of $(6 \mathrm{~m}-9 \mathrm{~m})$ and $(B L-12 m)$ groups where $(p=0.008)$ and $(p<0.001)$

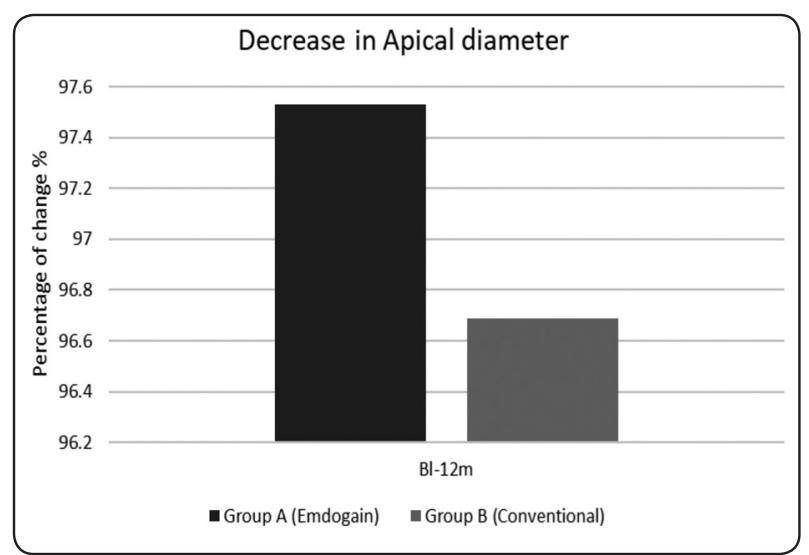

Fig. (8): Bar chart representing apical diameter for different groups

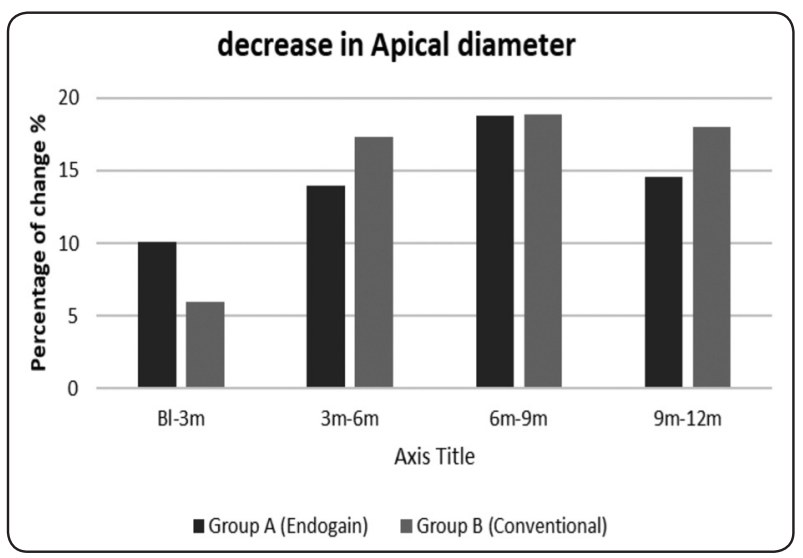

Fig. (9): Bar chart representing apical diameter for different groups throw the follow up intervals

respectively. No statistically significant difference was found between $(3 \mathrm{~m}-6 \mathrm{~m})$ and $(9 \mathrm{~m}-12 \mathrm{~m})$ where $(\mathrm{p}=0.726)$.

A statistically significant difference was found between $(6 m-9 m)$ and each of $(9 m-12 m)$ and $(\mathrm{BL}-12 \mathrm{~m})$ groups where $(\mathrm{p}=0.034)$ and $(\mathrm{p}<0.001)$ respectively.

Also, a statistically significant difference was found between $(9 \mathrm{~m}-12 \mathrm{~m})$ and $(\mathrm{BL}-12 \mathrm{~m})$ groups where $(\mathrm{p}<0.001)$.

\section{Group B (Conventional)}

There was a statistically significant difference between (BL-3m) (3m-6m), (6m-9m), (9m-12m) 
and $(\mathrm{BL}-12 \mathrm{~m})$ groups where $(\mathrm{p}<0.001)$.

A statistically significant difference was found between (BL-3m) and each of (3m-6m), (6m-9m), $(9 \mathrm{~m}-12 \mathrm{~m})$ and $(\mathrm{BL}-12 \mathrm{~m})$ groups where $(\mathrm{p}=0.004)$, $(\mathrm{p}<0.001),(\mathrm{p}=0.001)$ and $(\mathrm{p}<0.001)$ respectively.

No statistically significant difference was found between $(3 m-6 m)$ and each of $(6 m-9 m)$ and $(9 m-$ $12 \mathrm{~m})$ where $(\mathrm{p}=0.589)$ and $(\mathrm{p}=0.798)$. While a statistically significant difference was found between $(3 \mathrm{~m}-6 \mathrm{~m})$ and $(B L-12 \mathrm{~m})$ groups where $(\mathrm{p}<0.001)$.

No statistically significant difference was found between $(6 m-9 m)$ and $(9 m-12 m)$ where $(p=0.505)$. A statistically significant difference was found between $(6 \mathrm{~m}-9 \mathrm{~m})$ and $(\mathrm{BL}-12 \mathrm{~m})$ groups where $(\mathrm{p}<0.001)$.
A statistically significant difference was found between $(9 m-12 m)$ and (BL-12m) groups where $(\mathrm{p}<0.001)$.

\section{Relation between groups:}

a) Bl-3m:

There was a statistically significant difference between (Group A) and (Group B) groups where $(\mathrm{p}<0.001)$.

\section{b) $3 m-6 m$ :}

There was no statistically significant difference between (Group A) and (Group B) groups where $(\mathrm{p}=0.179)$.

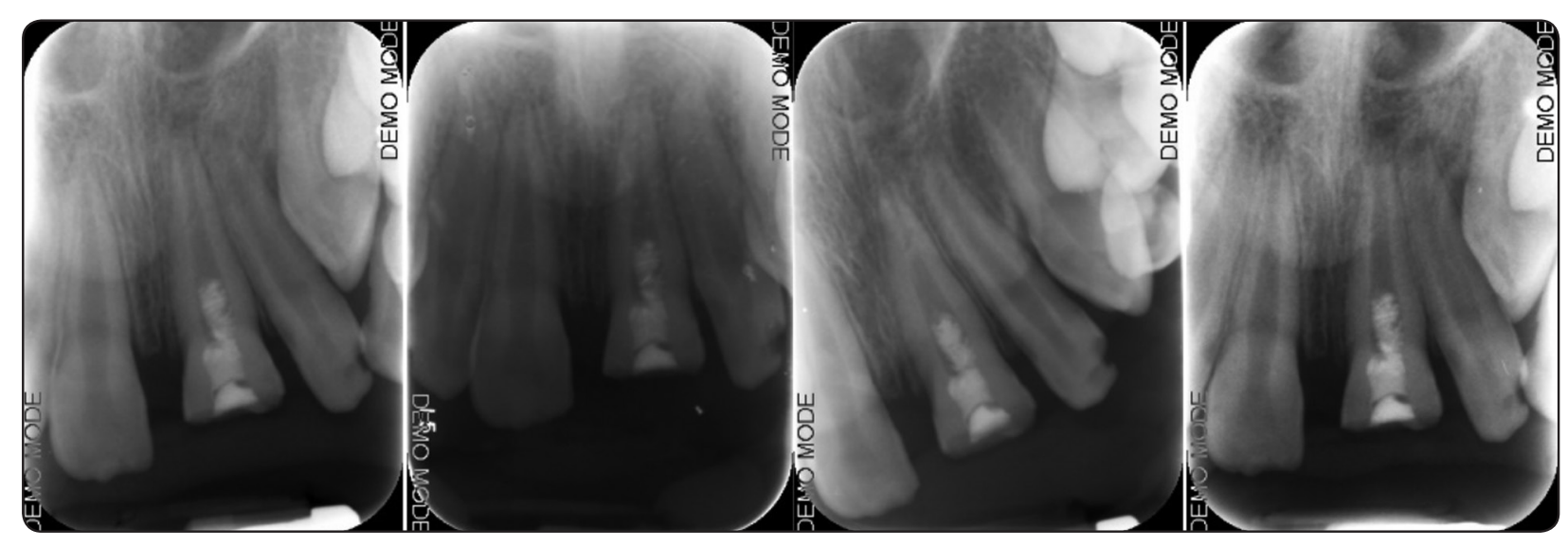

Fig. (10): Radiograph showing representative case of group A at 3-month,6-month, 9-month and 12-month interval

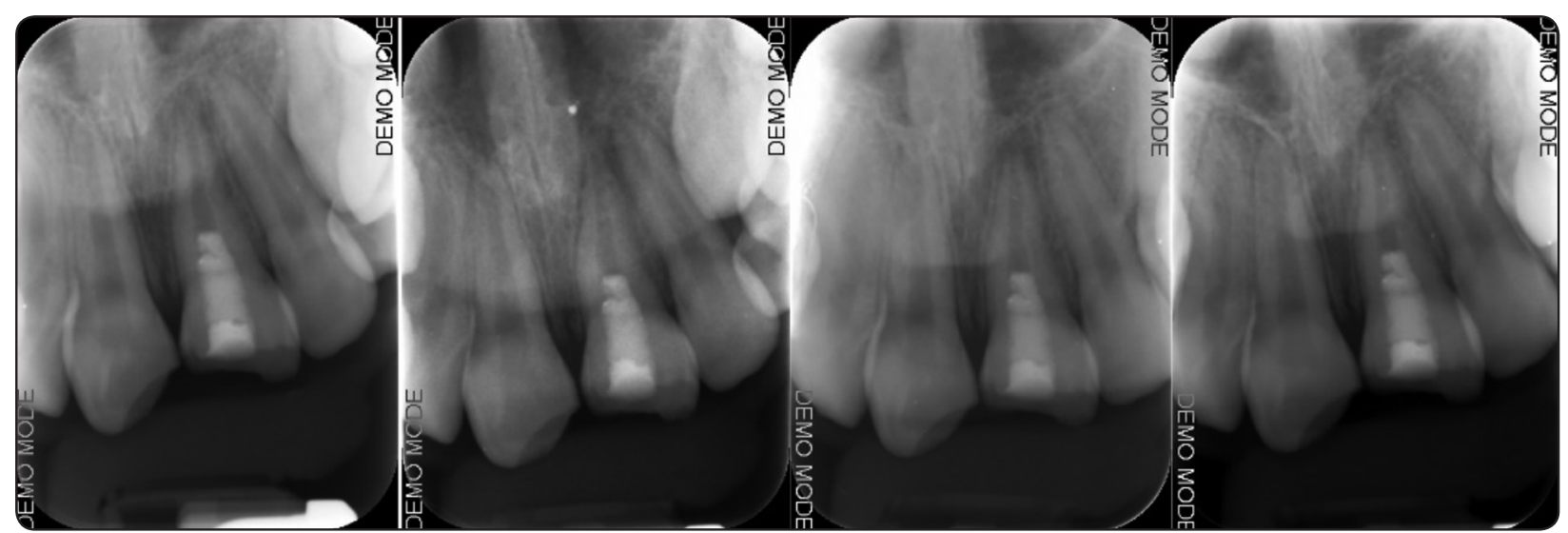

Fig. (11): Radiograph showing representative case of group B at 3-month,6-month, 9-month and 12-month interval 


\section{c) $6 m-9 m$ :}

There was no statistically significant difference between (Group A) and (Group B) groups where $(\mathrm{p}=0.907)$.

\section{d) $9 m-12 m:$}

There was no statistically significant difference between (Group A) and (Group B) groups where $(\mathrm{p}=0.147)$.

\section{e) Bl-12m:}

There was no statistically significant difference between (Group A) and (Group B) groups where $(\mathrm{p}=0.512)$.

\section{DISCUSSION}

Pulp insults during tooth maturation can hinder dentin formation and root growth. Condition of the pulp and root development stage are the key elements in the treatment approach. Many treatment options have been introduced like $\mathrm{Ca}(\mathrm{OH}) 2$ apexification, MTA apexification and placement of apical plug. However, these treatment options have several limitations such as the high risk of tooth fracture and long treatment duration. Moreover, the length and thickness of the roots do not increase significantly (Silujjai and Linsuwanont, 2017).

Since tissue regeneration cannot be accomplished with apexification, regenerative endodontic treatment was introduced as of late to treat permanent teeth with immature apex. Regenerative endodontic treatment is a treatment method intended to restore harmed pulp tissue with operable tissue which reestablishes the typical capacity of the pulp dentin structure. After regenerative endodontic treatment, proceeded with root development and hard tissue deposition on the dentinal wall can happen under ideal conditions (Lee et al., 2015).

Pulp revascularization is dependent on the capacity of remaining pulp and apical and periodontal stem cells to differentiate. These cells can generate a highly vascularized and a conjunctive rich living tissue, which can colonize the accessible pulp space. In this way, these undeveloped cells will separate into recently shaped odontoblasts that will instigate the arrangement of hard tissue (Namour and Theys, 2014).

Biologically, filling the root canal with vital tissue is better than filling it with foreign material (Saoud et al., 2016).

Tagelsir et al., 2016 discovered through a study that disinfection of the root canals for pulp regeneration faced two main problems when compared to conventional endodontic procedures. Firstly, the inability to utilize mechanical instruments through regenerative endodontics so that there is no enough space to the irrigants and medicaments due to the presence of the bacterial biofilm on the canal walls. Secondly, the difficulty in keeping stem cells vitality and bioactivity of dentin throughout the disinfection protocol. Increased concentrations of $\mathrm{NaOCl}$, TAP, or DAP were proved to be toxic to stem cells from apical papillae and affect negatively their adhesion, proliferation on dentin, and disrupt release of growth factors from dentin.

Having predictable long-term success of revascularization procedure requires effective root canal disinfection. The procedure requires minimal or no filing of the canal due to thinning of dentinal walls and the need of stem cells preservation. Be that as it may, in a histologic investigation of a failed REP treatment most microorganisms were noted in the apical and not the coronal segment of the waterway where a biofilm had shaped on the channel wall and infiltrated the dentinal tubules. The authors reasoned that based on the histobacteriologic discoveries that some level of mechanical instrumentation may likewise be needed to upset biofilm on the canal walls for proceeded with root advancement to happen (Lin et al., 2014; Lin and Kahler, 2017).

Chemo-mechanical instrumentation removes most of the bacteria, and necrotic pulp debris. However, this may be challenging due to thinning 
of dentinal walls and the need of stem cells preservation limits instrumentation of the root canal system makes the need of intracanal medication and irrigation is mandatory (Diogenes et al., 2014).

In our study $\mathrm{Ca}(\mathrm{OH}) 2$ was used as an intracanal medicament in accordance with the study conducted by Ruparel et al.,2012 which assess the survivability of human Stem cells of apical papilla (SCAPs) when using of TAP, DAP, and $\mathrm{Ca}(\mathrm{OH}) 2$ as an intra canal medication. He found that medicaments used at high concentration in regenerative procedures have a detrimental effect on the survival of SCAPs, except for $\mathrm{Ca}(\mathrm{OH}) 2$. The release of growth factors from dentine is also improved by $\mathrm{Ca}(\mathrm{OH}) 2$, whereas growth factor release was negatively influenced by antibiotic pastes (Galler et al., 2015).

In our study, Patients with luxation injuries were excluded due to the possibility of root resorption to occur (Soares et al., 2015), avulsed teeth which were immediately replanted as revitalization may occur naturally (Tambakad and Naidu, 2016) and badly decayed teeth requiring post and core for their restoration as the canal space needed for the blood clot will not be available.

The involved teeth were radiographed using radiograph paralleling gadgets to affirm inadequate root development. Such gadgets were used again for all the cases in order to standardize the resulting images, make it amenable for comparison and reduce any possibility for magnification or distortion. (Bose et al., 2009).

Irrigation with $1.5 \% \mathrm{NaOCl}$ (20 ml, $5 \mathrm{~min}$ ), using of irrigation needle while keeping a $2 \mathrm{~mm}$ distance between the tip of the needle and the vital tissue thus reducing the toxicity of $\mathrm{NaOCl}$ to apical tissue stem cells (Thomson and Kahler, 2010). $\mathrm{NaOCl}$ solution was used for copious passive irrigation as it proved effective in root canal disinfection in regenerative endodontic treatment and was found to significantly decrease bacterial infection inside canal with no need for synergistic irrigation (Nagata et al., 2014). $\mathrm{NaOCl}$ was the only utilized irrigant or combined with other irrigants in $97 \%$ of the clinical articles of regenerative endodontics (Kontakiotis et al., 2015).

Concentration of $\mathrm{NaOCl}$ mirrors the requirement for a harmony between tissue preservation and adequate disinfection (Martin et al., 2014), then Irrigation with $5 \mathrm{ml} 0.9 \%$ sodium chloride solution to limit the cytotoxic effects of $\mathrm{NaOCl}$ on vital tissue was done. $20 \mathrm{ml}$ of 17\% EDTA was used for irrigation. Growth factors are released from dentin in response to applied EDTA, such growth factors act to improve differentiation of stem cells of the dental pulp into odontoblast-like cells (Trevino et al., 2011). At the second visit after 2-4 weeks, of anesthesia without vasoconstrictor was used (Petrino et al., 2010).

The use of vasoconstrictors may negatively affect the ability to achieve bleeding in the canal, which is viewed as a significant step to attain a scaffold (Law, 2013) and the delivery of stem cells (Lovelace et al., 2011).

Induction of bleeding by mechanical irritation of periapical tissue by a $\mathrm{H}$-File in order to induce bleeding from the preapical area so as blood is allowed to fill the canal leaving $2 \mathrm{~mm}$ below the CEJ unfilled. Waiting for the blood clot to form for 15 min; The bleeding step in regenerative endodontic therapy is important as it allows stem cells to accumulate in the root canal space, such cells are needed for regeneration (Lovelace et al., 2011). The formed blood clot act as a scaffold for the stem cells immigrate inside the canal and contains necessary factors for differentiation and cell growth (Nosrat et al., 2012).

a thin homogeneous layer of MTA is used to fill the canal leaving $2 \mathrm{~mm}$ underneath the CEJ unfilled to avoid discoloration. MTA was used to seal off the canal orifice cervically for its well-established biocompatibility, tissue inductivity and good sealing ability (Parirokh et al., 2018). 
The set MTA act as a barrier facing the blood clot and provides the stem cells with molecules signaling for their growth. Therefore, MTA was used as an intracanal coronal barrier at the final session of regenerative endodontics in this study and in 85\% other similar studies (Bose et al., 2009; Kontakiotis et al., 2015). Meticulous compaction of MTA and subsequent precise adhesive composite restoration of the tooth was done in our study to prohibit root canal system contamination (Žižka et al., 2018).

In our study EMD gel was injected inside the canal on the blood clot to act as a matrix for the cells and white MTA was placed at the orifice, over the EMD and the blood clot to seal the canal orifice with a damp sterile cotton above. This application protocol was in accordance with other studies (Scarparo et al., 2012; Matsumoto et al., 2014 and Ns et al., 2018).

Follow-ups were performed after 3, 6, 9 and 12 months. Clinical and radiographic diagnostics were performed (Galler et al., 2016).

According to "The American Association of Endodontics clinical considerations for a regenerative procedure", the main goal of regenerative endodontic procedures is elimination of clinical signs/symptoms and resolution of apical periodontitis. Increased thickening of the canal walls and/or continued root development are considered secondary goals. All the cases in our study were completely functional since the start of treatment till now. The cases also demonstrated significant degree of root maturation over the 12 months of follow-up, the healing of periapical radiolucencies along with the continued thickening of the roots and apical maturation evaluated radiographically, can be explained by the ingrowth of progenitor cells from the periapical area (Rahim et al., 2019).

In group A (cases treated with Emdogain gel), the higher values found in dentin thickness \& apical closure indicate better regenerative treatment effects due to the use of EMD it promotes periodontal tissues regeneration such as bone, PDL, and cementum (Crea et al., 2008; Meyle et al., 2011). These results agree with (Scarparo et al., 2012) who has reported that EMD induces new cementum formation in the destroyed root apex. Normal tissue formation was triggered by EMD is caused by mesenchymal cells derived from the periodontal tissue surrounding the defect through the action of EMD applied to the alveolar bone defect.

Findings by Huang et al., 2008 showed that apical diseases induced by pulp death can stop root development. Hypothetically, SCAP can resist apical infection due to its proximity to the periodontal blood. These stem cells seem to be the source of odontoblasts that are responsible for the formation of root dentin and further root maturation.

Root development occurs by achieving the following: an increase in root thickness, an increase in root length, and the narrowing of the canal apically leading to the formation of the root apex. An increase in root length and the formation of the apex are functions of the apical papilla and Hertwig epithelial root sheath (Nosrat et al., 2013).

In most of our cases, improvement or resolution of the apical lesion was evident in approximately 9 months. Root elongation and apical closure, with thickening of the root canal walls, was evident after 12-months postoperatively. This is consistent with previously published articles (Wigler, 2013).

As for our results, there was significant increase in root length and root thickness, also a significant decrease of apical diameter at the end of whole follow up periods in all groups.

\section{CONCLUSION}

From the results of our study, we concluded that the use of EMD with MTA in pulp regeneration has no better effect in increasing the apical diameter than the use of MTA alone. 


\section{REFERENCES}

- Banchs F, Trope M. Revascularization of immature permanent teeth with apical periodontitis: new treatment protocol? Journal of endodontics. 2004 Apr 1;30(4):196-200.

- Bose R, Nummikoski P, Hargreaves K. A retrospective evaluation of radiographic outcomes in immature teeth with necrotic root canal systems treated with regenerative endodontic procedures. Journal of endodontics. 2009 Oct 1;35(10):1343-9.

- Bosshardt DD, Nanci A. Hertwig's epithelial root sheath, enamel matrix proteins, and initiation of cementogenesis in porcine teeth. J Clin Periodontol 2004;31:184 -92.

- Crea A, Dassatti L, Hoffmann O, Zafiropoulos GG, Deli G. Treatment of intrabony defects using guided tissue regeneration or enamel matrix derivative: A 3-year prospective randomized clinical study. Journal of periodontology. 2008 Dec;79(12):2281-9.

- Diogenes AR, Ruparel NB, Teixeira FB, Hargreaves KM. Translational science in disinfection for regenerative endodontics. Journal of endodontics. 2014 Apr 1;40(4):S52-7.

- Galler KM, Buchalla W, Hiller KA, Federlin M, Eidt A, Schiefersteiner M, Schmalz G. Influence of root canal disinfectants on growth factor release from dentin. Journal of endodontics. 2015 Mar 1;41(3):363-8.

- Galler KM, Krastl G, Simon S, Van Gorp G, Meschi N, Vahedi B, Lambrechts P. European Society of Endodontology position statement: revitalization procedures. International endodontic journal. 2016 Aug;49(8):717-23.

- Hammarström L. Enamel matrix, cementum development and regeneration. J Clin Periodontol 1997;24:658 - 68.

- Huang GT, Sonoyama W, Liu Y, Liu H, Wang S, Shi S. The hidden treasure in apical papilla: the potential role in pulp/dentin regeneration and bioroot engineering. Journal of endodontics. 2008 Jun 1;34(6):645-51.

- Kontakiotis EG, Filippatos CG, Tzanetakis GN, Agrafioti A. Regenerative endodontic therapy: a data analysis of clinical protocols. Journal of endodontics. $2015 \mathrm{Feb}$ 1;41(2):146-54.

- Krebsbach PH, Lee SK, Matsuki Y, Kozak CA, Yamada KM, Yamada Y. Full-length sequence, localization, and chromosomal mapping of ameloblastin: a novel toothspecific gene. J Biol Chem 1996;271:4431-5.

- Law AS. Considerations for regeneration procedures. Pediatric dentistry. 2013 Apr 15;35(2):141-52.
- Lee BN, Moon JW, Chang HS, Hwang IN, Oh WM, Hwang YC. A review of the regenerative endodontic treatment procedure. Restorative dentistry \& endodontics. 2015 Aug;40(3): 179.

- Lin LM, Kahler B. A review of regenerative endodontics: current protocols and future directions. Journal of Istanbul University Faculty of Dentistry. 2017;51(3 Suppl 1):S41.

- $\quad$ Lin LM, Shimizu E, Gibbs JL, Loghin S, Ricucci D. Histologic and histobacteriologic observations of failed revascularization/revitalization therapy: a case report. Journal of endodontics. 2014 Feb 1;40(2):291-5.

- $\quad$ Lovelace TW, Henry MA, Hargreaves KM, Diogenes A. Evaluation of the delivery of mesenchymal stem cells into the root canal space of necrotic immature teeth after clinical regenerative endodontic procedure. Journal of endodontics. 2011 Feb 1;37(2):133-8.

- Martin DE, De Almeida JF, Henry MA, Khaing ZZ, Schmidt CE, Teixeira FB, Diogenes A. Concentrationdependent effect of sodium hypochlorite on stem cells of apical papilla survival and differentiation. Journal of endodontics. 2014 Jan 1;40(1):51-5.

- Matsumoto N, Minakami M, Hatakeyama J, Haruna C, Morotomi T, Izumi T, Anan H. Histologic evaluation of the effects of Emdogain gel on injured root apex in rats. Journal of endodontics. 2014 Dec 1;40(12):1989-94.

- Meyle J, Hoffmann T, Topoll H, Heinz B, Al-Machot E, Jervøe-Storm PM, Meiß C, Eickholz P, Jepsen S. A multicentre randomized controlled clinical trial on the treatment of intra-bony defects with enamel matrix derivatives/synthetic bone graft or enamel matrix derivatives alone: Results after 12 months. Journal of clinical periodontology. $2011 \mathrm{Jul} ; 38(7): 652-60$.

- $\quad$ Nagata JY, Soares AJ, Souza-Filho FJ, Zaia AA, Ferraz CC, Almeida JF, Gomes BP. Microbial evaluation of traumatized teeth treated with triple antibiotic paste or calcium hydroxide with $2 \%$ chlorhexidine gel in pulp revascularization. Journal of endodontics. 2014 Jun 1;40(6):778-83.

- Nagy MM, Tawfik HE, Hashem AA, Abu-Seida AM. Regenerative potential of immature permanent teeth with necrotic pulps after different regenerative protocols. Journal of endodontics. 2014 Feb 1;40(2):192-8.

- Namour M, Theys S. Pulp revascularization of immature permanent teeth: a review of the literature and a proposal of a new clinical protocol. The Scientific World Journal. 2014 Oct 14;2014. 
- Nosrat A, Homayounfar N, Oloomi K. Drawbacks and unfavorable outcomes of regenerative endodontic treatments of necrotic immature teeth: a literature review and report of a case. Journal of endodontics. 2012 Oct 1;38(10):1428-34.

- $\quad$ Nosrat A, Li KL, Vir K, Hicks ML, Fouad AF. Is pulp regeneration necessary for root maturation?. Journal of endodontics. 2013 Oct 1;39(10):1291-5.

- $\quad$ NS CG, Coelho BS, Deliberador TM, Junior DR, BarattoFilho F, Florez FL, Zielak JC, Leonardi DP. Six-Year Follow-Up of Immature Tooth Revascularization With Enamel Matrix Proteins. Compendium of continuing education in dentistry (Jamesburg, NJ: 1995). 2018 Jul 1;39(7):e9-12.

- Östby BN. The role of the blood clot in endodontic therapy an experimental histologic study. Acta Odontologica Scandinavica. 1961 Jan 1;19(3-4):323-53.

- $\quad$ Parirokh M, Torabinejad M, Dummer PM. Mineral trioxide aggregate and other bioactive endodontic cements: an updated overview-part I: vital pulp therapy. International endodontic journal. 2018 Feb;51(2):177-205.

- Petrino JA, Boda KK, Shambarger S, Bowles WR, McClanahan SB. Challenges in regenerative endodontics: a case series. Journal of endodontics. 2010 Mar 1;36(3):536-41.

- Rahim AS,Abdelgawad F, Abd Alsamed AM, Moheb DM,ElDokky NA. Case Report: Single visit photo-activated disinfection in regenerative endodontics. F1000Research.2019;8.

- Robinson C, Brookes SJ, Shore RC, Kirkham J. The developing enamel matrix: nature and function. Eur J Oral Sci 1998;106:282-91.

- Ruparel, N. B., Teixeira, F. B., Ferraz, Caio \& Diogenes, A. Direct Effect of Intracanal Medicaments on Survival of Stem Cells of the Apical Papilla. J. Endod. 38, 1372-1375 (2012).

- Saoud TM, Martin G, Chen YH, Chen KL, Chen CA, Songtrakul K, Malek M, Sigurdsson A, Lin LM. Treatment of mature permanent teeth with necrotic pulps and apical periodontitis using regenerative endodontic procedures: a case series. Journal of endodontics. 2016 Jan 1;42(1):57-65.

- Scarparo RK, Dondoni L, Böttcher DE, Grecca FS, Figueiredo JA, Batista Jr EL. Apical periodontium response to enamel matrix derivative as an intracanal medication in rat immature teeth with pulp necrosis: radiographic and histologic findings. Journal of endodontics. 2012 Apr 1;38(4):449-53.

- Silujjai J, Linsuwanont P. Treatment outcomes of apexification or revascularization in nonvital immature permanent teeth: a retrospective study. Journal of endodontics. 2017 Feb 1;43(2):238-45.

- Soares AJ, Souza GA, Pereira AC, Vargas-Neto J, Zaia AA, Silva EJ. Frequency of root resorption following trauma to permanent teeth. Journal of oral science. 2015;57(2):73-8.

- Tagelsir A, Yassen GH, Gomez GF, Gregory RL. Effect of antimicrobials used in regenerative endodontic procedures on 3-week-old Enterococcus faecalis biofilm. Journal of endodontics. 2016 Feb 1;42(2):258-62.

- Tambakad PB, Naidu J. Pulp and periodontal regeneration of an avulsed permanent mature incisor using platelet-rich plasma after delayed replantation: a 12-month clinical case study. Journal of endodontics. 2016 Jan 1;42(1):66-71.

- Thomson A, Kahler B. Regenerative endodontics-biologically-based treatment for immature permanent teeth: a case report and review of the literature. Australian Dental Journal. 2010 Dec;55(4):446-52.

- Torabinejad M, Chivian N. Clinical applications of mineral trioxide aggregate. J Endod 1999;25:197-205.Safavi KE, N.

- Trevino EG, Patwardhan AN, Henry MA, Perry G, Dybdal-Hargreaves N, Hargreaves KM, Diogenes A. Effect of irrigants on the survival of human stem cells of the apical papilla in a platelet-rich plasma scaffold in human root tips. Journal of endodontics. 2011 Aug 1;37(8):1109-15.

- Wigler R, Kaufman AY, Lin S, Steinbock N, Hazan-Molina $\mathrm{H}$, Torneck CD. Revascularization: a treatment for permanent teeth with necrotic pulp and incomplete root development. J Endod. 2013 Mar;39(3):319-26

- Žižka R, Šedý J, Voborná I. Retreatment of failed revascularization/revitalization of immature permanent tooth-A case report. Journal of clinical and experimental dentistry. 2018 Feb;10(2):e185. 